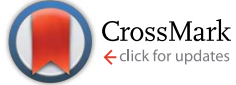

Cite this: J. Mater. Chem. A, 2016, 4, 14550

Received 8th August 2016 Accepted 30th August 2016

DOI: $10.1039 / c 6 t a 06782 d$

\section{Bis(1,1-bis(2-pyridyl)ethane)copper(ı/ı) as an efficient redox couple for liquid dye-sensitized solar cells $\dagger$}

\author{
Jiayan Cong, $\ddagger^{\mathrm{a}}$ Dominik Kinschel, $\hbar^{\mathrm{ab}}$ Quentin Daniel, ${ }^{\mathrm{C}}$ Majid Safdari, ${ }^{\mathrm{a}}$ \\ Erik Gabrielsson, ${ }^{\mathrm{b}}$ Hong Chen, ${ }^{\mathrm{c}}$ Per H. Svensson, ${ }^{\text {cd }}$ Licheng Sun ${ }^{\mathrm{ce}}$ and Lars Kloo*a
}

www.rsc.org/MaterialsA

A new redox couple, $\left[\mathrm{Cu}(\text { bpye })_{2}\right]^{+/ 2+}$, has been synthesized, and applied in dye-sensitized solar cells (DSSCs). Overall efficiencies of $9.0 \%$ at 1 sun and $9.9 \%$ at 0.5 sun were obtained, which are considerably higher than those obtained for cells containing the reference redox couple, $\left[\mathrm{Co}(\mathrm{bpy})_{3}\right]^{2+/ 3+}$. These results represent a record for copper-based complex redox systems in liquid DSSCs. Fast dye regeneration, sluggish recombination loss processes, faster electron self-exchange reactions and suitable redox potentials are the main reasons for the observed increase in efficiency. In particular, the main disadvantage of cobalt complex-based redox couples, charge-transport problems, appears to be resolved by a change to copper complex redox couples. The results make copper complex-based redox couples very promising for further development of highly efficient DSSCs.

Since Grätzel and O'Regan significantly improved the efficiency of dye-sensitized solar cells (DSSCs) in 1991, ${ }^{1}$ DSSCs have attracted significant interest and qualified as one of the most promising candidates for the next generation of commercial solar cells. ${ }^{2}$ The liquid electrolyte redox couple is one of the central components of the DSSC, which has the task to transfer the charges from the oxidized dye molecules to the counter electrode (or vice versa). ${ }^{3}$ Before 2011, the most efficient DSSCs

${ }^{a}$ Applied Physical Chemistry, School of Chemical Science and Engineering, Department of Chemistry KTH Royal Institute of Technology, Teknikringen 30, SE-100 44 Stockholm, Sweden.E-mail: Lakloo@kth.se

${ }^{b}$ Dyenamo AB, Greenhouse Labs, Teknikringen 38A, SE-114 28 Stockholm, Sweden 'Organic Chemistry, School of Chemical Science and Engineering, Department of Chemistry, KTH Royal Institute of Technology, Teknikringen 30, SE-100 44 Stockholm, Sweden

${ }^{d}$ SP Process Development, Forskargatan, SE-151 21 Södertälje, Sweden

${ }^{e}$ State Key Laboratory of Fine Chemicals, DUT-KTH Joint Education and Research Center on Molecular Devices, Dalian University of Technology (DUT), 116024 Dalian, China

$\dagger$ Electronic supplementary information (ESI) available. CCDC 1459030 and 1457921. For ESI and crystallographic data in CIF or other electronic format see DOI: $10.1039 / \mathrm{c} 6$ ta06782d

\$ These authors contributed equally to this work. were based on the iodide/triiodide redox couple. ${ }^{4-7}$ However, the intrinsic properties of the redox system with respect to corrosivity towards metal contact materials, photoreactivity and relatively negative redox potential have limited its potential for large-scale production and further efficiency improvement. In 2011, the Hagfeldt and Sun groups combined organic dyes with long bulky chains and one-electron redox systems based on cobalt complexes. ${ }^{8}$ This strategy opened the possibility of record DSSCs based on cobalt complex redox couples. Subsequently, the Grätzel group reported a new record efficiency using the $\left[\mathrm{Co}(\mathrm{bpy})_{3}\right]^{2+/ 3+}$ redox system. ${ }^{9}$ By now, the most efficient dyesensitized solar cell based on a single dye showed 13.0\% conversion efficiency including the $\left[\mathrm{Co}(\mathrm{bpy})_{3}\right]^{2+/ 3+}$ redox couple, ${ }^{10}$ and the use of co-sensitization has provided an even higher efficiency of $14.0 \% .^{11}$ The advantage of the cobalt redox couple is that its properties can be modified by changing its ligands. However, because of the large molecular size of the cobalt redox couple components, mass and charge transport may become a problem. ${ }^{12}$ In 2005, the Fukuzumi group introduced blue copper redox systems into DSSCs, but the efficiencies of the cells based on these redox systems were not higher than $1.5 \% .^{13}$ In 2011, the Wang group combined the $\left[\mathrm{Cu}(\mathrm{dmp})_{2}\right]^{+/ 2+}$ system and the organic dye C218, and achieved $7.0 \%$ conversion efficiency, representing the record efficiency for copper redox-based liquid DSSCs. ${ }^{14}$ In 2015, the Hagfeldt group reported a new type of $\left[\mathrm{Cu}(\mathrm{dmp})_{2}\right]^{+/ 2+}$-based solid-state DSSC, by evaporating the electrolyte from the liquid DSSC, referred to as "zombie solar cells", and showed an impressive $8.3 \%$ efficiency. ${ }^{15}$ However, the function of the "zombie cells" is not fully understood.

Copper is a very abundant element in the crust of earth allowing copper to be retrieved at a low price. The copper complex redox systems are particularly interesting as efficient systems in liquid DSSCs because of their native property of fast electron self-exchange. This property may reduce charge transport limitations, and thus the electrolyte may allow higher overall conversion efficiencies. However, so far, DSSC devices showing record efficiencies have been based on Co complex- 
based redox couples. One reason can be attributed to the positive redox potential (with respect to the normal hydrogen electrode) of the copper redox system $\left[\mathrm{Cu}(\mathrm{dmp})_{2}\right]^{+/ 2+}$ in relation to the highest occupied molecular orbital (HOMO) level of the commonly used sensitizing dyes leading to low current densities and consequently low overall efficiencies.

In the present work, a new copper-based redox couple involving 1,1-bis(2-pyridyl)ethane (bpye) ligands is used in the DSSCs showing promising efficiency and highlights the potential of $\mathrm{Cu}$-based redox couples for future record DSSC devices. The synthesis and detailed characterization of the copper complexes, $\left[\mathrm{Cu}^{\mathrm{I}}(\text { bpye })_{2}\right]\left(\mathrm{PF}_{6}\right) /\left[\mathrm{Cu}^{\mathrm{II}}\left(\mathrm{bpye}_{2}\right]\left(\mathrm{PF}_{6}\right)_{2}\right.$, can be found in the ESI. $\dagger$ The structures of the copper complexes and the sensitizing dye used in the DSSC devices are shown in Fig. 1 and 2 .

A copper complex-based electrolyte with a similar composition and concentration to the commonly used cobalt complexbased electrolytes was formulated and applied to the DSSC devices. The composition of the electrolyte used (Cu-bpye) was $0.22 \mathrm{M}\left[\mathrm{Cu}^{\mathrm{I}}\left(\mathrm{bpye}_{2}\right]\left(\mathrm{PF}_{6}\right), 0.05 \mathrm{M}\left[\mathrm{Cu}^{\mathrm{II}}\left(\mathrm{bpye}_{2}\right]\left(\mathrm{PF}_{6}\right)_{2}, 0.10 \mathrm{M}\right.\right.$ $\mathrm{LiClO}_{4}$ and $0.20 \mathrm{M}$ TBP in acetonitrile, while that of the reference cobalt redox-based electrolyte (Co-bpy) was $0.22 \mathrm{M}$ $\left[\mathrm{Co}^{\mathrm{II}}(\mathrm{bpy})_{3}\right]\left(\mathrm{PF}_{6}\right)_{2}, 0.05 \mathrm{M}\left[\mathrm{Co}^{\mathrm{III}}(\mathrm{bpy})_{3}\right]\left(\mathrm{PF}_{6}\right)_{3}, 0.10 \mathrm{M} \mathrm{LiClO}_{4}$ and $0.20 \mathrm{M}$ TBP in acetonitrile.

The photovoltaic properties of the DSSC devices containing the copper and cobalt complex-based electrolytes are shown in Table 1. All devices were fabricated with a $5+5 \mu \mathrm{m} \mathrm{TiO}_{2}$ film, and were sensitized with the dye LEG4 (Fig. 1). PEDOT counter
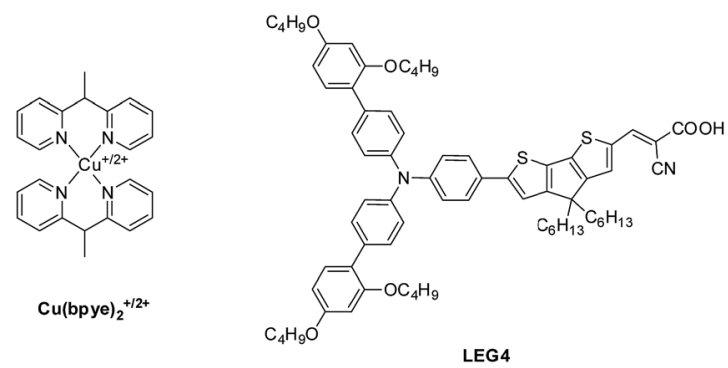

Fig. 1 The structures of $\left[\mathrm{Cu}(\text { bpye })_{2}\right]^{+/ 2+}$ (the counter ion is $\mathrm{PF}_{6}{ }^{-}$) and the sensitizing dye LEG4.
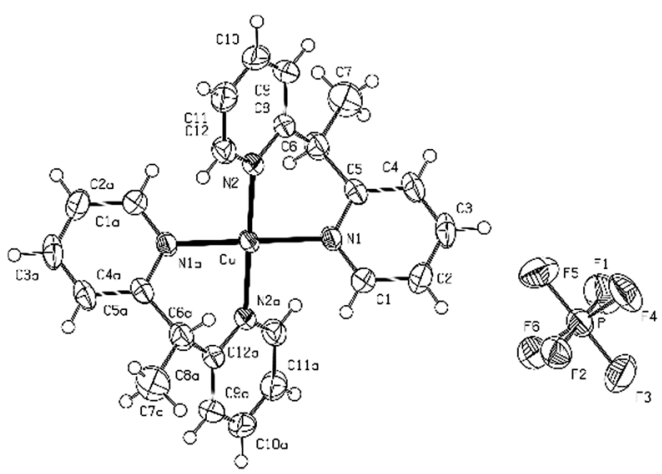

Fig. 2 The crystal structure of [Cu(bpye $\left.)_{2}\right]\left(\mathrm{PF}_{6}\right)_{2}$ shown as an ORTEP drawing with ellipsoids representing a $50 \%$ probability surface.
Table 1 Photovoltaic characteristics of DSSC devices containing the copper and cobalt complex-based electrolytes ${ }^{a}$

\begin{tabular}{lllll}
\hline Electrolyte $^{b}$ & $V_{\mathrm{OC}}{ }^{c}(\mathrm{mV})$ & $J_{\mathrm{SC}}{ }^{c}\left(\mathrm{~mA} \mathrm{~cm}^{-2}\right)$ & $\mathrm{FF}^{c}(\%)$ & $\eta^{c}(\%)$ \\
\hline Cu-bpye & $904 \pm 9$ & $13.8 \pm 0.4$ & $71.8 \pm 0.6$ & $9.0 \pm 0.1$ \\
Co-bpy & $867 \pm 3$ & $12.9 \pm 0.2$ & $68.3 \pm 0.6$ & $7.6 \pm 0.1$
\end{tabular}

${ }^{a} \mathrm{TiO}_{2}$ thickness $5 \mu \mathrm{m}$ (active layer) $+5 \mu \mathrm{m}$ (scattering layer) treated with $\mathrm{TiCl}_{4}$; working area: $0.25 \mathrm{~cm}^{2}$. Five devices were assembled for each electrolyte. ${ }^{b}$ The cobalt electrolyte Co-bpy had a standard composition corresponding to $0.22 \mathrm{M}\left[\mathrm{Co}^{\mathrm{II}}(\mathrm{bpy})_{3}\right]\left(\mathrm{PF}_{6}\right)_{2}, \quad 0.05 \mathrm{M}$ $\left[\mathrm{Co}^{\mathrm{II}}(\mathrm{bpy})_{3}\right]\left(\mathrm{PF}_{6}\right)_{3}, 0.10 \mathrm{M} \mathrm{LiClO}_{4}$ and $0.20 \mathrm{M}$ TBP in acetonitrile. The electrolyte Cu-bpye had a similar composition and concentration to the cobalt one, with the composition $0.22 \mathrm{M}\left[\mathrm{Cu}^{\mathrm{I}}\left(\mathrm{bpye}_{2}\right)_{2}\right]\left(\mathrm{PF}_{6}\right), 0.05 \mathrm{M}$ $\left[\mathrm{Cu}^{\mathrm{II}}(\text { bpye })_{2}\right]\left(\mathrm{PF}_{6}\right)_{2}, 0.10 \mathrm{M} \mathrm{LiClO}_{4}$ and $0.20 \mathrm{M}$ TBP in acetonitrile. ${ }^{c}$ The devices were investigated using a black mask with an aperture area of $0.25 \mathrm{~cm}^{2}$ and the photovoltaic data were recorded under full sun AM 1.5G illumination.

electrodes were used for the device fabrication, because of better performance compared to platinized counter electrodes (see Fig. S3†). This can be attributed to a higher surface area and a reduced charge transfer resistance at the electrolyte/counter electrode interface. ${ }^{18}$ The details of fabrication can be found in the ESI. $\dagger$ The devices were studied under full sun AM 1.5G illumination ( $100 \mathrm{~mW} \mathrm{~cm} \mathrm{~cm}^{-2}$ ) and with a $0.25 \mathrm{~cm}^{2}$ black mask with the same area as the active area of the DSSC devices.

The devices based on the $\left[\mathrm{Cu}(\text { bpye })_{2}\right]^{+/ 2+}$ redox system showed a $904 \mathrm{mV}$ open-circuit voltage $\left(V_{\mathrm{OC}}\right)$, a $13.8 \mathrm{~mA} \mathrm{~cm} \mathrm{~cm}^{-2}$ short-circuit current density $\left(J_{\mathrm{SC}}\right)$ and a $72 \%$ fill factor $(\mathrm{FF})$, yielding $9.0 \%$ in overall conversion efficiency $(\eta)$. All the photovoltaic parameters recorded for the devices based on the copper complex redox system are higher than the corresponding parameters of the cobalt complex-based devices, exhibiting $9.0 \%$ efficiency as compared to $7.6 \%$. $9.0 \%$ is currently the record efficiency reported for devices based on copper complex redox shuttles. The higher $V_{\text {OC }}$ recorded for $\mathrm{Cu}$-based DSSC devices can be affected by two factors. One is the difference in electrolyte redox potential, and the other is the recombination loss reactions at the $\mathrm{TiO}_{2}$ /dye interface. From the cyclic voltammetry (CV) measurement, the redox potential of $\left[\mathrm{Cu}(\text { bpye })_{2}\right]^{+/ 2+}$ is $0.59 \mathrm{~V}$ vs. NHE (normal hydrogen electrode), which is $30 \mathrm{mV}$ higher than that of $\left[\mathrm{Co}(\mathrm{bpy})_{3}\right]^{2+/ 3+}, 0.56 \mathrm{~V}$ (ref. 8) (the $\mathrm{CV}$ data can be found in Fig. 3, and the measurement conditions are specified in the ESI $\dagger$ ). The more positive redox

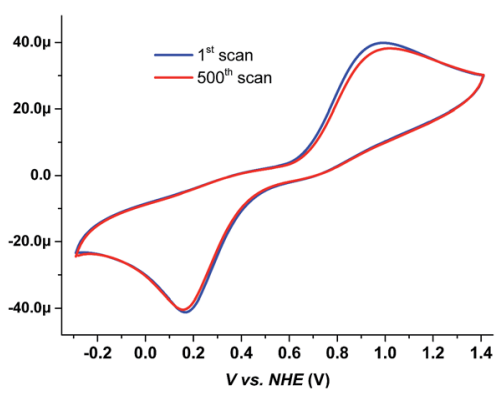

Fig. 3 Multiple $\mathrm{CV}$ scans of $\left[\mathrm{Cu}\left(\mathrm{bpye}_{2}\right]\left(\mathrm{PF}_{6}\right)\right.$ in acetonitrile. 
potential of the copper complex-based redox couple contributes to the better $V_{\mathrm{OC}}$ performance. Lower recombination losses were also observed for the $\left[\mathrm{Cu}(\text { bpye })_{2}\right]^{+/ 2+}$ redox system, than for the $\left[\mathrm{Co}(\mathrm{bpy})_{3}\right]^{2+/ 3+}$ one. This also gives a positive contribution to the $V_{\text {OC }}$ (details can be found in the latter part of this paper). The higher $J_{\mathrm{SC}}$ recorded for the Cu-based devices can be ascribed to the faster regeneration of the dye cation by the $\mathrm{Cu}$ complexes, ${ }^{\mathbf{1 4}}$ as well as better electrolyte charge transport. The latter effect is most likely caused by the smaller molecular size and faster electron self-exchange rates for the copper complexes. ${ }^{13}$ The reason for the higher FF observed is less clear, since there is no obvious catalytic difference at the counter electrode (details can be found in the latter part of this paper).

The photovoltaic properties of the devices based on the different redox couples under different light intensities were also recorded. The data are shown in Table 2, and the $J-V$ curves are shown in Fig. 4 . The devices containing the $\left[\mathrm{Cu}(\text { bpye })_{2}\right]^{+/ 2+}$ couple show higher $J_{\mathrm{SC}}$ and $V_{\mathrm{OC}}$ under all three light intensities. Calculated from the value of $J_{\mathrm{SC}}$ and light intensity, the efficiency of the device based on the copper redox system at 1.0 sun intensity, $14.1 \mathrm{~mA}$ per $\mathrm{cm}^{2}$ per sun, is $96.6 \%$ of that at $0.5 \mathrm{sun}$. At the same time, the corresponding value for the cobalt-based system is $93.5 \%$, indicating that the devices based on the copper redox couple experience less charge-transport problems than those based on the cobalt redox couple. For $\left[\mathrm{Cu}(\text { bpye })_{2}\right]^{+/ 2+}$ based devices the $V_{\mathrm{OC}}$ decreases by $10 \mathrm{mV}$ and $53 \mathrm{mV}$ going from 1.0 sun to 0.5 sun, and from 0.5 sun to 0.1 sun, respectively. This is a smaller decrease than the observed corresponding changes of 20 and $110 \mathrm{mV}$ for $\left[\mathrm{Co}(\mathrm{bpy})_{3}\right]^{2+/ 3+}$-based devices. This indicates less recombination losses at the $\mathrm{TiO}_{2} /$ dye interface for devices containing $\left[\mathrm{Cu}(\text { bpye })_{2}\right]^{+/ 2+}$. The higher $V_{\mathrm{OC}}$ and $J_{\mathrm{SC}}$ at low light intensity show promising potential of copper-based DSSCs for indoor use.

The incident photon-to-current conversion efficiencies (IPCEs) of the DSSC devices based on the copper and cobalt redox couples have also been recorded and the data are shown

Table 2 Photovoltaic characteristics of DSSC devices containing the copper and cobalt complex-based electrolytes ${ }^{a}$

\begin{tabular}{llllll}
\hline & Light density $^{b}$ & $V_{\mathrm{OC}}{ }^{c}(\mathrm{mV})$ & $J_{\mathrm{SC}}{ }^{c}\left(\mathrm{~mA} \mathrm{~cm}^{-2}\right)$ & $\mathrm{FF}^{c}(\%)$ & $\eta^{c}(\%)$ \\
\hline Cu-bpye & 1.0 sun & 895 & 14.1 & 71.3 & 9.0 \\
& 0.5 sun & 885 & 7.3 & 76.4 & 9.9 \\
Co-bpy & 0.1 sun & 842 & 1.3 & 80.8 & 8.7 \\
& 1.0 sun & 870 & 12.9 & 68.8 & 7.7 \\
& 0.5 sun & 850 & 6.9 & 71.0 & 8.3 \\
& 0.1 sun & 760 & 1.2 & 75.3 & 7.0
\end{tabular}

${ }^{a} \mathrm{TiO}_{2}$ thickness $5 \mu \mathrm{m}$ (active layer) $+5 \mu \mathrm{m}$ (scattering layer) treated with $\mathrm{TiCl}_{4}$; working area: $0.25 \mathrm{~cm}^{2}$. Five devices were assembled for each electrolyte. ${ }^{b}$ The cobalt electrolyte Co-bpy had a standard composition corresponding to $0.22 \mathrm{M}\left[\mathrm{Co}^{\mathrm{II}}(\mathrm{bpy})_{3}\right]\left(\mathrm{PF}_{6}\right)_{2}, \quad 0.05 \mathrm{M}$ $\left[\mathrm{Co}^{\mathrm{II}}(\mathrm{bpy})_{3}\right]\left(\mathrm{PF}_{6}\right)_{3}, 0.10 \mathrm{M} \mathrm{LiClO}_{4}$ and $0.20 \mathrm{M}$ TBP in acetonitrile. The electrolyte Cu-bpye had a similar composition and concentration to the cobalt one, with the composition $0.22 \mathrm{M}\left[\mathrm{Cu}^{\mathrm{I}}(\mathrm{bpye})_{2}\right]\left(\mathrm{PF}_{6}\right), 0.05 \mathrm{M}$ $\left[\mathrm{Cu}^{\mathrm{II}}(\text { bpye })_{2}\right]\left(\mathrm{PF}_{6}\right)_{2}, 0.10 \mathrm{M} \mathrm{L_{ClO }}$ and $0.20 \mathrm{M}$ TBP in acetonitrile. ${ }^{c}$ The devices were investigated using a black mask with an aperture area of $0.25 \mathrm{~cm}^{2}$ and the photovoltaic data were recorded under full sun AM 1.5G illumination.

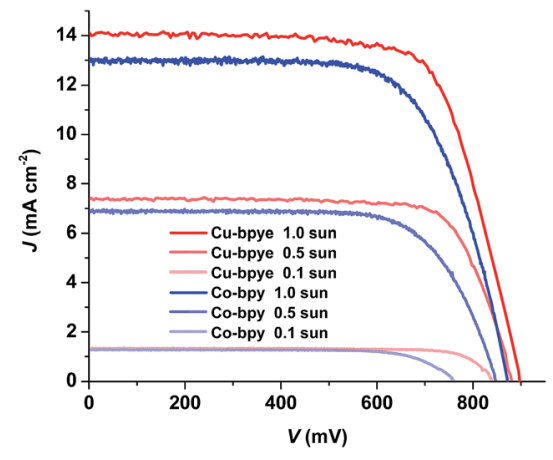

Fig. 4 Photocurrent density-voltage curves $(J-V)$ of the DSSC devices containing the $\left[\mathrm{Cu}(\mathrm{bpye})_{2}\right]^{+/ 2+}$ and $\left[\mathrm{Co}(\mathrm{bpy})_{3}\right]^{2+/ 3+}$-based electrolytes under different light intensities.
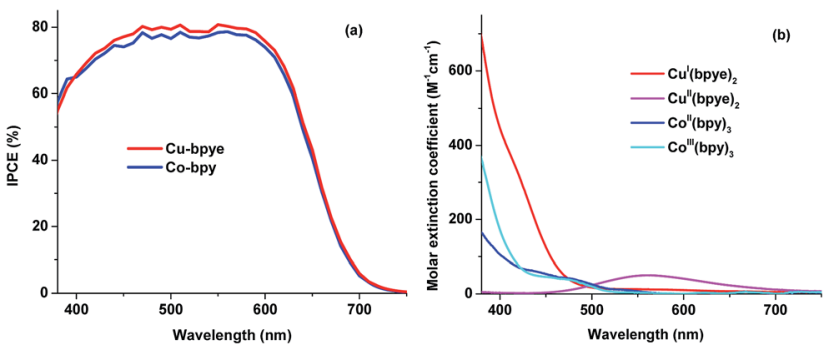

Fig. 5 IPCE spectra (a) of the DSSC devices based on the $\left[\mathrm{Cu}(\mathrm{bpye})_{2}\right]^{+/ 2+}$ and $\left[\mathrm{Co}(\text { bpy })_{3}\right]^{2+/ 3+}$ redox couples, and (b) UV-Vis light absorption characteristics of the different redox system components.

in Fig. 5a. As can be noted, the devices containing the copper redox system show higher IPCEs for most of the absorption region but slightly lower below $400 \mathrm{~nm}$; the short-wavelength response is caused by the higher light absorption by $\mathrm{Cu}^{\mathrm{I}}(\text { bpye })_{2}$. Moreover, a small decrease in the IPCE around $550 \mathrm{~nm}$ can also be observed. The reason for this dip is caused by light absorption of $\mathrm{Cu}^{\mathrm{II}}(\text { bpye })_{2}$. The UV-Vis absorption of the different redox species is shown in Fig. $5 \mathrm{~b}$.

The electron lifetime of the devices containing the $\mathrm{Cu}$ (bpye) ${ }_{2}^{+/ 2+}$ and $\mathrm{Co}(\mathrm{bpy})_{3}{ }^{2+/ 3+}$ redox couples was investigated. The results are shown in Fig. 6. The difference in redox potential between $\mathrm{Cu}$ (bpye $)_{2}{ }^{+/ 2+}$ and $\mathrm{Co}(\mathrm{bpy})_{3}{ }^{2+/ 3+}$ is taken into account by using the pseudo-Fermi level as the abscissa $\left(E_{\mathrm{F}, \mathrm{n}}=E_{\text {redox }}-V_{\mathrm{OC}}\right)$. It is clear that devices based on $\mathrm{Cu}(\text { bpye })_{2}{ }^{+/ 2+}$ display considerably longer lifetime than those based on $\operatorname{Co}(\mathrm{bpy})_{3}{ }^{2+/ 3+}$.

Electrochemical impedance spectroscopy (EIS) was used to study the charge-transfer processes in the DSSC devices based on the different redox systems. The measurements were performed under an illumination of one sun intensity. Fig. 7 shows the Nyquist plots of the DSSCs containing the copper and cobalt redox couples. At higher frequencies, at the left side of the spectra, the charge-resistance (a few ohms) at the counter electrode does not show any significant dependence on the redox system. This indicates that the catalytic properties of the PEDOT counter electrode material are as good for the copper redox system as for the cobalt one. It is notable that the PEDOT counter electrode represents an excellent material for the 


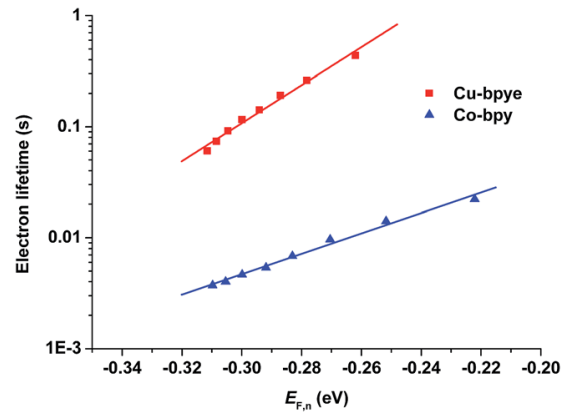

Fig. 6 The electron lifetime of the devices with $\mathrm{Cu}(\text { bpye })_{2}{ }^{+/ 2+}$ and $\mathrm{Co}(\mathrm{bpy})_{3}^{2+/ 3+}$ redox couples.

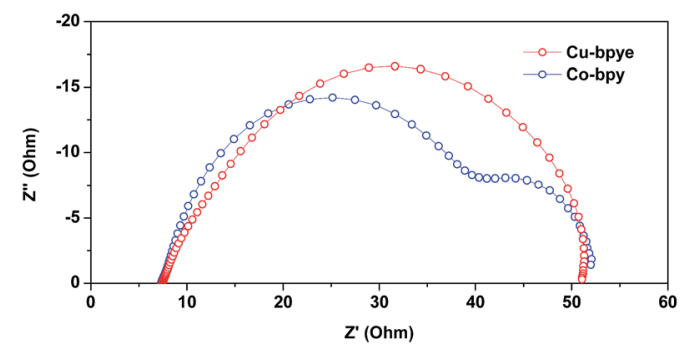

Fig. 7 Nyquist plots of the EIS data for the DSSC devices based on the $\left[\mathrm{Cu}(\text { bpye })_{2}\right]^{+/ 2+}$ and $\left[\mathrm{Co}(\mathrm{bpy})_{3}\right]^{2+/ 3+}$ redox couples.

reduction of the oxidized components of the metal-complex systems, and the performance of PEDOT is one of the main reasons for the high efficiency recorded for the copper-based DSSC devices. The big semicircle in the middle part of the spectra mainly originates from the resistance at the $\mathrm{TiO}_{2} /$ dye interface. Calculated from the EIS data, the resistance at the $\mathrm{TiO}_{2} /$ dye-electrolyte interface is $44 \Omega$ for the $\left[\mathrm{Cu}(\text { bpye })_{2}\right]^{+/ 2+}$ system, which is higher than that recorded for the $\left[\mathrm{Co}(\mathrm{bpy})_{3}\right]^{2+/ 3+}$ system, $35 \Omega$. This difference is consistent with a lower recombination loss in the devices based on $\left[\mathrm{Cu}(\text { bpye })_{2}\right]^{+/ 2+}$ than those based on $\left[\mathrm{Co}(\mathrm{bpy})_{3}\right]^{2+/ 3+}$, and these results can possibly also be linked to the high photovoltage produced by the copper-based devices. On the right side of the spectra, at lower frequencies, one extra semicircle can be observed for the devices based on the $\left[\mathrm{Co}(\mathrm{bpy})_{3}\right]^{2+/ 3+}$ redox system. This indicates a higher resistance in the cobaltcomplex based electrolyte, $17 \Omega$. Under the same conditions, the electrolyte resistance of the copper-complex based electrolyte cannot be identified. There are two possible reasons; one is that the diffusion resistance in the copper-based electrolyte is very low. The other is that the time scale of charge transfer in the copper complex-based electrolyte is similar to that of the recombination process at the $\mathrm{TiO}_{2} /$ dye-electrolyte interface. Both alternative explanations highlight a more efficient charge transfer in the copper complex-based electrolyte. In total, the EIS data show that the charge-transport problem essentially is resolved by the copper complex-based electrolyte. This most likely can be linked to the smaller molecular size of the $\left[\mathrm{Cu}(\text { bpye })_{2}\right]^{+/ 2+}$ complexes, and judging from fundamental studies on metal complex self-exchange

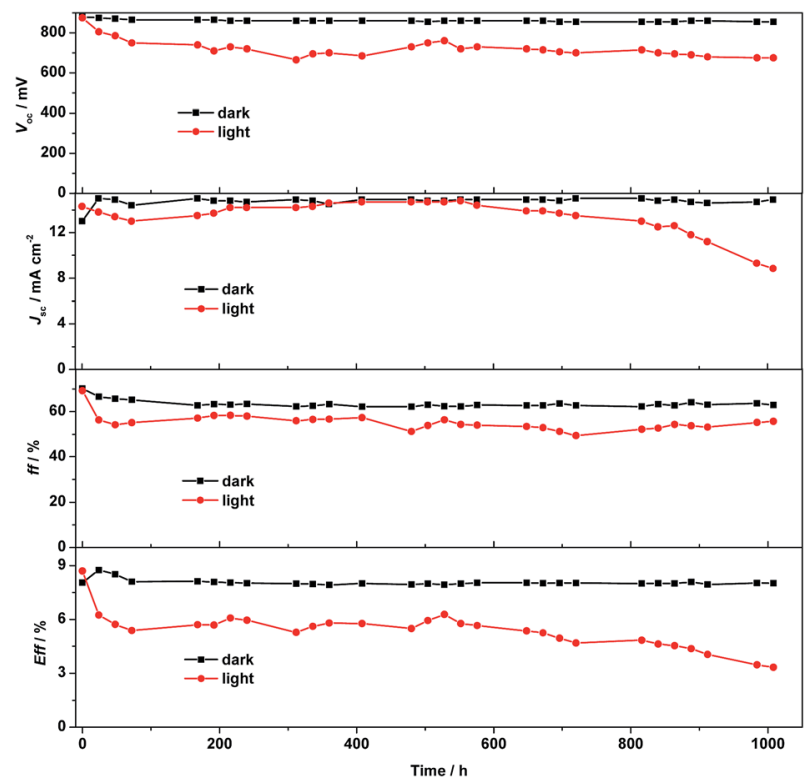

Fig. 8 The stability of DSSCs fabricated using the $\left[\mathrm{Cu}(\text { bpye })_{2}\right]\left(\mathrm{PF}_{6}\right) /$ $\left[\mathrm{Cu}(\text { bpye })_{2}\right]\left(\mathrm{PF}_{6}\right)_{2}$ redox couple studied under dark and under light soaking at $40^{\circ} \mathrm{C}$ for $1000 \mathrm{~h}$.

rates, much faster electron self-exchange rates ${ }^{13}$ are expected as compared to those of the $\left[\mathrm{Co}(\mathrm{bpy})_{3}\right]^{2+/ 3+}$ complexes.

The long-term stability of the devices with $\left[\mathrm{Cu}(\text { bpye })_{2}\right]^{+/ 2+}$ under different conditions was also investigated. Due to the high reproducibility of DSSCs (within $\pm 0.1 \%$ in efficiency), statistics on multiple cells add no significant information. ${ }^{17}$ The data in Fig. 8 show an excellent device stability under dark conditions. Multiple CV scans, as seen in Fig. 3, also show a good chemical stability of the system. The slight change in the $\mathrm{CV}$ response could be ascribed to evaporation of the solvent. Ageing under light exposure shows that after an initial drop in efficiency from $9 \%$ to $6 \%$, the system also remains photochemically stable up to about 700 hours of exposure. The initial drop in efficiency, within the first $20-40$ hours of light exposure, is most likely caused by a light-induced ligand exchange involving the solvent and/or TBP in the $\mathrm{Cu}(\mathrm{II}) / \mathrm{Cu}(\mathrm{I})$ redox pair or oxidization of the $\mathrm{Cu}(\mathrm{I})$-complex redox species. After the initial degradation, the system remains stable up to 700 hours of exposure, when the solvent visibly can be observed to have evaporated and the device quickly loses its performance. The aging test under light exposure thus rather became a test of the device sealing, rather than the electrolyte stability.

\section{Conclusions}

In summary, a new redox couple, $\left[\mathrm{Cu}(\text { bpye })_{2}\right]^{+/ 2+}$, has been synthesized, and applied in dye-sensitized solar cells. Overall efficiencies of $9.0 \%$ at 1 sun, and $9.9 \%$ at 0.5 sun were obtained, which are considerably higher than those obtained for cells containing the reference redox couple, $\left[\mathrm{Co}(\mathrm{bpy})_{3}\right]^{2+/ 3+}$. These results represent a record for copper-based complex redox systems in liquid DSSCs. Fast dye regeneration, sluggish recombination loss processes, faster electron self-exchange 
reactions and suitable redox potentials are the main reasons for the observed high efficiencies. In particular, the main disadvantage of cobalt complex-based redox couples, the chargetransport problems, appears to be resolved by the coppercomplex redox couples. Also, device chemical and photochemical stability is quite good though indicating a redox system ligand-exchange or $\mathrm{Cu}(\mathrm{I})$ oxidation under light exposure that deserves further investigation. ${ }^{\mathbf{1 6}}$ Nevertheless, the present results also indicate that device stability depends on the persistence of redox- and light-induced equilibria in the DSSCs, rather than on the integrity of the initial compounds added to the electrolyte; control of the electrolyte solution chemistry is consequently one key factor for achieving long-term device stability. The results make $\mathrm{Cu}$ complex-based redox systems very promising for further development of efficient DSSCs.

\section{Acknowledgements}

This work is supported by the Swedish Research Council, the Swedish Energy Agency and the Knut \& Alice Wallenberg Foundation, and the Natural Science Foundation of China (21120102036 and 91233201). Dr Qian Gao is acknowledged for help in the synthesis.

\section{Notes and references}

1 B. O'Regan and M. Grätzel, Nature, 1991, 353, 737-740.

2 M. Grätzel, Nature, 2001, 414, 338-344.

3 A. Hagfeldt, G. Boschloo, L. Sun, L. Kloo and H. Pettersson, Chem. Rev., 2010, 110, 6595-6663.

4 Y. Chiba, A. Islam, Y. Watanabe, R. Komiya, N. Koide and L. Han, Jpn. J. Appl. Phys., 2006, 45, L638.

5 C.-Y. Chen, M. Wang, J.-Y. Li, N. Pootrakulchote, L. Alibabaei, C.-h. Ngoc-le, J.-D. Decoppet, J.-H. Tsai,
C. Grätzel, C.-G. Wu, S. M. Zakeeruddin and M. Grätzel, ACS Nano, 2009, 3, 3103-3109.

6 Q. Yu, Y. Wang, Z. Yi, N. Zu, J. Zhang, M. Zhang and P. Wang, ACS Nano, 2010, 4, 6032-6038.

7 W. Zeng, Y. Cao, Y. Bai, Y. Wang, Y. Shi, M. Zhang, F. Wang, C. Pan and P. Wang, Chem. Mater., 2010, 22, 1915-1925.

8 S. M. Feldt, E. A. Gibson, E. Gabrielsson, L. Sun, G. Boschloo and A. Hagfeldt, J. Am. Chem. Soc., 2010, 132, 16714-16724.

9 A. Yella, H.-W. Lee, H. N. Tsao, C. Yi, A. K. Chandiran, M. K. Nazeeruddin, E. W.-G. Diau, C.-Y. Yeh, S. M. Zakeeruddin and M. Grätzel, Science, 2011, 334, 629634.

10 S. Mathew, A. Yella, P. Gao, R. Humphry-Baker, F. E. CurchodBasile, N. Ashari-Astani, I. Tavernelli, U. Rothlisberger, K. Nazeeruddin Md and M. Grätzel, Nat. Chem., 2014, 6, 242-247.

11 K. Kakiage, Y. Aoyama, T. Yano, K. Oya, J.-i. Fujisawa and M. Hanaya, Chem. Commun., 2015, 51, 15894-15897.

12 J. Cong, X. Yang, L. Kloo and L. Sun, Energy Environ. Sci., 2012, 5, 9180-9194.

13 S. Hattori, Y. Wada, S. Yanagida and S. Fukuzumi, J. Am. Chem. Soc., 2005, 127, 9648-9654.

14 Y. Bai, Q. Yu, N. Cai, Y. Wang, M. Zhang and P. Wang, Chem. Commun., 2011, 47, 4376-4378.

15 M. Freitag, Q. Daniel, M. Pazoki, K. Sveinbjornsson, J. Zhang, L. Sun, A. Hagfeldt and G. Boschloo, Energy Environ. Sci., 2015, 8, 2634-2637.

16 W. L. Hoffeditz, M. J. Katz, P. Deria, G. E. Cutsail Iii, M. J. Pellin, O. K. Farha and J. T. Hupp, J. Phys. Chem. C, 2016, 120, 3731-3740.

17 K. Hara, Z.-S. Wang, Y. Cui, A. Furube and N. Koumura, Energy Environ. Sci., 2009, 2(10), 1109-1114.

18 S. M. Feldt, E. A. Gibson, G. Wang, G. Fabregat, G. Boschloo and A. Hagfeldt, Polyhedron, 2014, 82, 154-157. 